\title{
EFFECT OF IRRIGATION BY GATED PIPES AND TRADITIONAL IRRIGATION SYSTEM WITH MIXED WATER ON SOIL, DRAINAGE WATER AND CROP.
}

\author{
Abousrie, A. Farag. ${ }^{1}$, Yasser, M. Atta ${ }^{2}$ and Mostafa, S. El-komy ${ }^{2}$
}

\section{ABSTRACT}

This study was carried out in Sahl El-Tena (North West of Sinai Peninsula, Egypt; Latitude $30^{\circ} 59^{\backslash} 7^{\prime \prime}$ and longitude $32^{\circ} 26^{\backslash} 55^{\text {') }}$ during the growth seasons 2013, 2014 and 2015. The experimental area was 11.49 hectares, and the experimental site was characterized by a Mediterranean arid climate, with a mean annual rainfall of $33.3 \mathrm{~mm}$ and a mean daily temperature of $21.8^{\circ} \mathrm{C}$. The main source of irrigation water is El-Slam Channel where water is a mixure of both waste water and Nile fresh water at a ratio of 1:1. Two crops: maize (Zea mays l.) and wheat (Triticum aestivum l.) were chosen and grown because of their high economic and strategic values. Crop yield, water use efficiency and soil properties were concerned under two types of surface irrigation system which were traditional and modified surface irrigation by gated pipes. Statistical analysis was carried out by the SPSS program to drive the significant variance between means. The obtained results revealed that, values of yield and water use efficiency (WUE) with gated pipes were higher than the corresponding ones under the traditional system for the two crops under study. Also, using gated pipes increased both soil EC by small values during the growth seasons but it increased by about 3 (ds $\mathrm{m}^{-}$ 1) at 14 August, 2013 and 6 April, 2015. Moreover, the quantity of drainage water under traditional system was higher than under the gated pipe system, therefore, the EC of drainage water under gated pipes system was higher than the corresponding one under the traditional method.

Key words: Water use efficiency, modified surface irrigation by gated pipes, surface irrigation system, drainage water and water qualify.

1- Lecturer of Agriculture engineering, Department of Agricultural and Biosystems Engineering, Faculty of Agriculture, Benha Univeristy, Egypt. Abousrie.ahmad@fagr.bu.edu.eg

2- Researcher in Drainage Research Institute (DRI), National Water Research Center (NWRC), Egypt. 


\section{INTRODUCTION}

$\mathrm{M}$

ost area of Egypt is desert of semi - arid climate. Irrigation of the arable soils depends on the Nile River which contributes to requirement for irrigation. However, the Nile fresh water is not sufficient for irrigation of additional desert areas which involve the potential expansion soils. Moreover, the problem of irrigation water deficiency is expected to increase after the building of the Ethiopian Renaissance Dam.

In general, Nile Valley and Delta soils are mainly irrigated by a surface irrigation system which has low efficiency that ranged from 47 up to $50 \%$ ICARDA, (2011). Due to limited water resources, arid climate and fast increasing in population, more water is required for decreasing the gap between the demand and available water. Therefore, developing surface irrigation by using a gated - pipe technique provides an important tool for improvement of its performance. Uniform water flow may be regulated by adjusting the size of the outlet opening manually with some difficulties, which may be decreased water application. Osman, 2000 stated that good design of gated pipes with precision land-leveling may amend the water distribution uniformity and save irrigation water by about $29 \%$ in wheat.

The low efficiency of surface irrigation system is the main problem. The improving efficiency of surface irrigation system by using the gated pipes (GP), which consider a new technique for distributing the irrigation water into furrows to save the applied irrigation water (Ali and Mohammed, 2015).

The applied of GP reduced water application by $923.81 \mathrm{~m}^{3} \cdot \mathrm{ha}^{-1}$ and increased grain and dry wheat yields by $5.7 \%$ and $3.4 \%$, respectively compared with the traditional irrigation system which gave the highest quantity of applied water $\left(6423.81 \mathrm{~m}^{3} \cdot \mathrm{ha}^{-1}\right)$ (Ali and Mohammed, 2015). El-Sayed, 1998 illustrated that the required effected head for more efficiency and short flexible orifice may be attached to the outlets of gated pipes to dissipate energy and minimize erosion at furrow with operation head $50 \mathrm{~cm}$ or less under clay soil.

Osman, 2003 mentioned that using gated pipes increased the yield and water use efficiencies (WUE) of wheat by $5.2 \%$ and $137 \%$, respectively 
while decreased the applied water $29.9 \%$ compared with the traditional system.

Maize (Zea mays L.) is one of the most important cereal crops grown principally during the summer season in Egypt. Great attention has been paid to increase the total production of maize. This could be achieved by using high yielding varieties, avoid water flooding and deficit stress. The responses of plants to flooding or deficit water depend on the genotype, growth stage, level and duration of stress, and physical parameters of the soil (Groote and Kimenju, 2012).

Water scarcity is a growing global problem, which challenges the sustainable development and gives a constraint on producing enough food to meet increasing food requirements. Egypt is mainly an agricultural country. The main water resource is the Nile River. The agriculture sector consumes about $80 \%-85 \%$ of Nile water annually (EI-Quosy, 2011).

The cultivated area of old land is about 2.7 million hectares irrigated by traditional surface irrigation according to the data issued by the (Yates and Strzepek, 1998).

Surface irrigation is the most widely used system as a conventional practice at the Egyptian farmers. Despite this progressive water shortage, farmers continue to use surface irrigation system. Poor management, uniformity and distribution of water have been cited as the most frequent problems of surface irrigation system, which caused waterlogging, salinization and less water use efficiency (Abou Kheira, 2009).

Water application efficiency gives a general indicator of the irrigation system performance and the depth of water root zone. Water infiltration into the soil is a key to crop production and salinity control. More than $45 \%$ of water applied is lost by the deep soil drainage and surface runoff (Karrou, et. al. 2012).

Saving water and improving water use efficiency need to be developed. Water saved will be used to increase the cultivated area and overall crop production. Developing surface irrigation using gated pipes is a new technique, which uses to distribute water to furrow as a strategy based on water saving. The gated pipe has many advantages: 1) Requires a small area of land to install the system; 2) reduces the seepage and evaporation losses and improve water distribution; 3) low cost and maintenance 
requirements and 4) Improves human public health by avoiding contact with infected water.

The main objectives of this study were focused upon saving water by using modified surface irrigation by gated pipes (GP) In addition study the effect of applying mixed water on yield, Water Use Efficiency (WUE), water table and soil properties for wheat and maize crops.

\section{1- Materials and methods}

\subsection{Experimental site.}

The experimental area was 11.49 hectares; the experimental site was characterized by a Mediterranean arid climate, with a mean annual rainfall of $33.3 \mathrm{~mm}$ and a mean daily temperature of $21.8^{\circ} \mathrm{C}$. These data were measured by a private weather station located at the experimental site. The soil texture of the experimental site was sandy loam having soil field capacity of $18 \%$, soil wilting point 7.00 , soil bulk density of 1.36 g. $\mathrm{cm}^{-3}$ and infiltration rate of $0.33 \mathrm{~m} \cdot \mathrm{h}^{-1}$ as presented in Table 1. Two commercial crops (maize (Zea mays l.) and wheat (Triticum aestivum l.)) were cultivated during the growth seasons 2013, 2014 and 2015.

\subsection{Irrigation system}

The main source of irrigation water in the experimental site is El- Slam canal, which having an average discharge about 2.4 Milliard cubic meter annually and it satisfied by mixing Nile water and drainage water along the canal at ratio of 1:1. The drainage water is lifted from Bahr Hadus and lower Serou Drain. Traditional surface irrigation and Gated pipe systems were used to irrigate wheat and maize crops. The irrigation water was delivered to the experimental site using centrifugal pump, which has 40 $\mathrm{HP}(29.84 \mathrm{KW})$ and $120 \mathrm{~m}^{3} \cdot \mathrm{h}^{-1}$.

The chemical, nutritive and non-nutritive analysis of El-Salam canal water are presented in Tables (1 and 2).

\subsection{Drainage system}

Subsurface drainage system was installed at $35 \mathrm{~m}$ spacing between laterals. It consists of 24 field drains at $1.4 \mathrm{~m}$ depth, as shown in Figure 2. All field drains discharged their drainage water in manholes and collected into two main collectors that divided the pilot area into four separated portions. The collectors discharged into branch drain (Drain 6) and then the branch drain discharged into Baloza drain. 


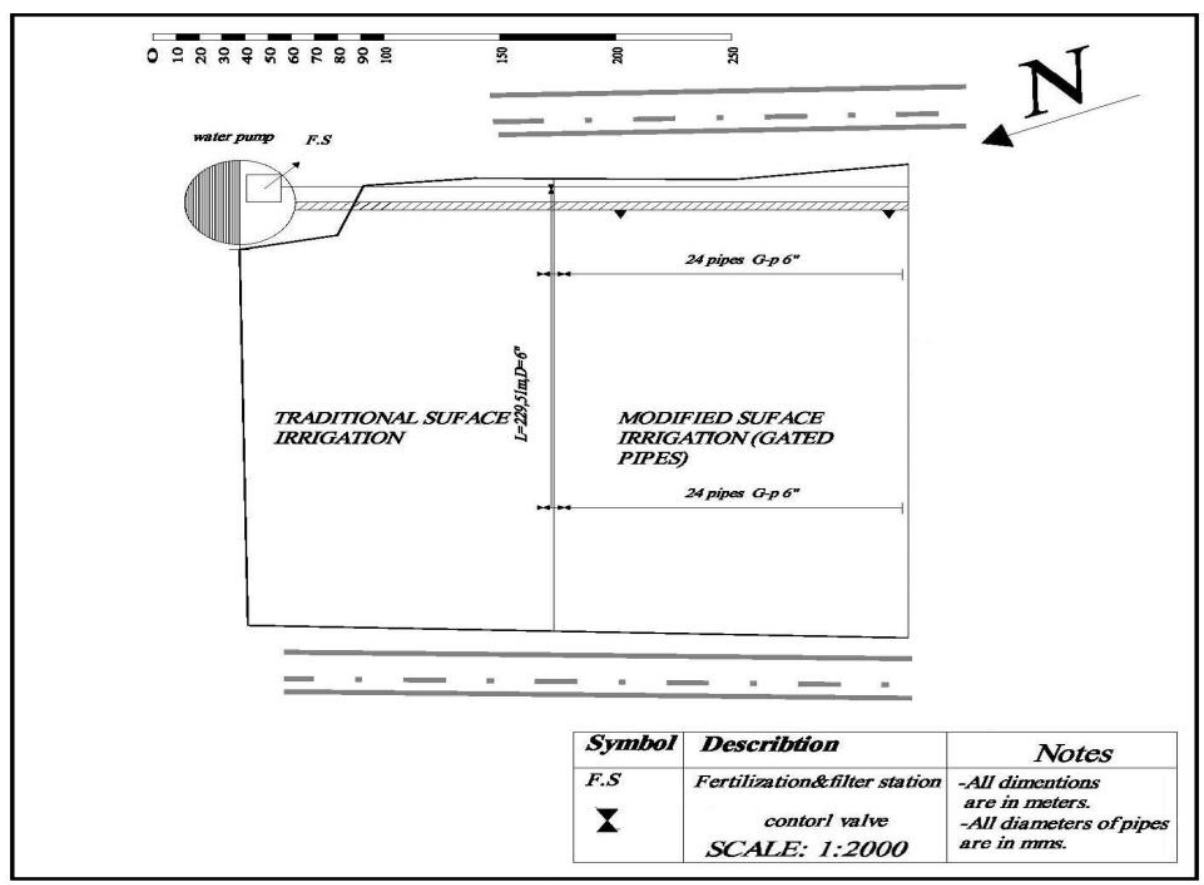

Figure 1: Irrigation network that located at the experiment site.

Table (1): Chemical analysis of water used in each irrigation event.

\begin{tabular}{|c|c|c|c|c|c|c|c|c|c|}
\hline \multirow{2}{*}{$\begin{array}{c}\text { Sodium } \\
\text { adsorption } \\
\text { Ratio } \\
(\text { SAR) }(\%)\end{array}$} & \multicolumn{7}{|c|}{ Soluble ions (mmolc $\left.\mathbf{L}^{-1}\right)$} & \multirow{2}{*}{ 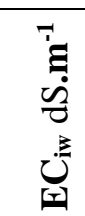 } & \multirow[b]{2}{*}{ pH } \\
\hline & $\mathrm{SO}_{4}^{--}$ & $\mathrm{Cl}^{-}$ & $\mathrm{HCO}_{3}{ }^{-}$ & $\mathbf{K}^{+}$ & $\mathbf{N a}^{+}$ & $\mathbf{M g}^{++}$ & $\mathbf{C a}^{++}$ & & \\
\hline 6.24 & 4.83 & 7.7 & 0.5 & 0.32 & 9.3 & 2.25 & 2.2 & 1.25 & 7.73 \\
\hline
\end{tabular}

Table (2): Some nutritive and non-nutritive elements of the used irrigation water

\begin{tabular}{|c|c|c|c|c|c|c|c|c|c|c|}
\hline $\begin{array}{c}\text { Non-nutritive heavy } \\
\text { metals }\left(\mathrm{mg} \mathrm{L}^{-1}\right)\end{array}$ & \multicolumn{8}{|c|}{ Nutritive elements in $\mathrm{mg} \mathrm{L}^{-1}$ (some macro and } \\
\hline $\mathrm{Cd}$ & $\mathrm{Ni}$ & $\mathrm{Pb}$ & $\mathrm{Cu}$ & $\mathrm{Zn}$ & $\mathrm{Mn}$ & $\mathrm{Fe}$ & $\mathrm{Al}$ & $\mathrm{P}$ & $\mathrm{HN} 4-\mathrm{N}$ & $\mathrm{NO}-\mathrm{N}$ \\
\hline 0.001 & $>0.001$ & 0.04 & 0.06 & 0.02 & 0.06 & 0.12 & 0.03 & 0.33 & 3.26 & 11.21 \\
\hline
\end{tabular}

\subsection{Applied irrigation water in m3.fed-1.}

Reference evapotranspiration (ET) and crop evapotranspiration (ETc) for wheat and maize were calculated by CropWat model and crop coefficient was taken from FAO publications Allen et. al, 1998. The irrigation period was 10 days between each irrigation event. The meteorological data was measured by using the (El-Esmaelia) station. 


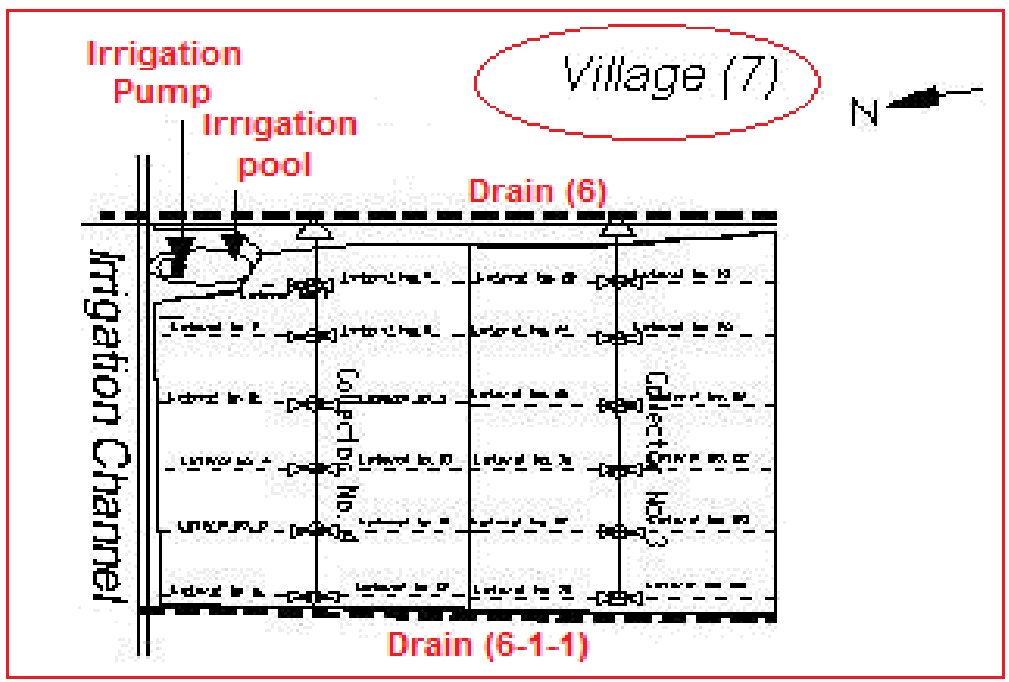

Figure 2: Drainage network which served in the experimental site.

Charts 1 and 2 illustrated the relation among time, consumptive use and applied irrigation water, for traditional and gated pipe irrigation systems. Water requirements increased from June to august and decreased from August to September for maize crop, but for wheat crop it sharply increased from November to May. From this chart, we can show clearly that, the higher values were found under traditional surface irrigation system.

Figures (3 and 4), shown the water requirements in $\mathrm{m}^{3} /$ fed for maize and wheat, respectively, along growing season.

\subsection{Statistical analysis}

Statistical analysis was carried out by SPSS program to drive the significant variance between means.

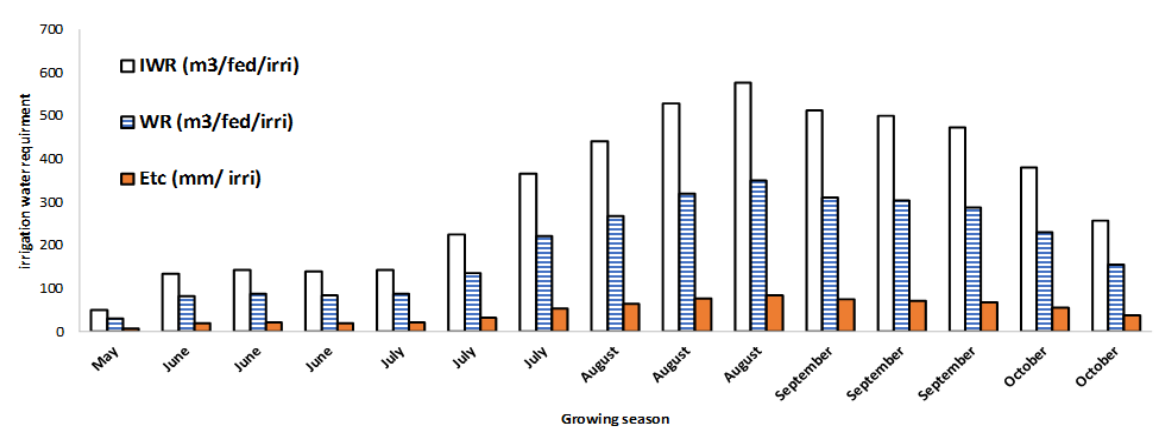

Figure (3). The consumed water and applied irrigation water for maize crop. 


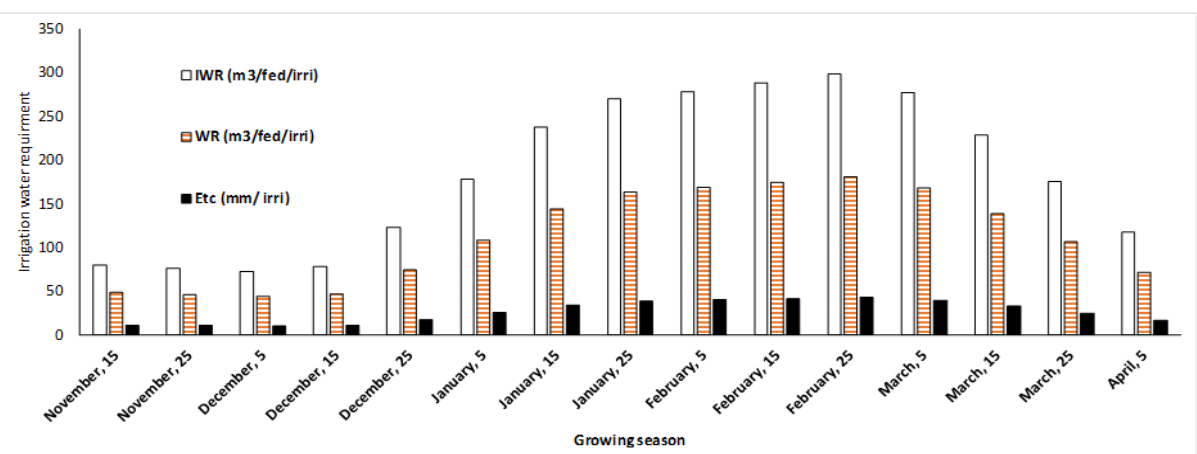

Figure (4). The consumed water and applied irrigation water for wheat crop.

\section{RESULTS AND DISCUSSIONS}

Comparable results obtained from this study were between traditional surface irrigation system and modified surface irrigation system by gated pipes, in terms of water management, soil properties, yield and WUE and drainage management. The comparison between the two systems was based on the significance of these parameters which drived from the statistical analysis.

\subsection{Yield and WUE}

Figures (5, 6, 7 and 8) show the seasonal course of yield water use efficiency (WUE) for both wheat and maize crops during seasons from 2013 until 2015 under traditional and gated pipe irrigation systems (GP). Results showed that, the highest values of yield and WUE were 2.25, 2.5 and 2.65 ton fed $^{-1}$ under GP for all three seasons, respectively. All parameter values were increased with time due to the decreased of soil EC from $2.27 \pm 0.45\left(\mathrm{ds} \mathrm{m}^{-1}\right)$ at the beginning of study to $1.59 \pm 0.15$ (ds $\mathrm{m}^{-1}$ ) at the end of season 2015 as discussed.

On the other hand, the statistical analysis showed that, the values of yield for both wheat and maize were significant by 0.025 for all of them and the values of (FUE) were significant by 0.043 for maize and 0.046 for wheat but the values of (WUE) were not significant for maize and wheat. Charts (3, 4, 5 and 6) explain the comparison between traditional and gated pipes irrigation system since 2013, 2014 and 2015.the yield, (WUE) and (FUE) all of them were increased from 2013 to 2015. The highest values were found under gated pipes irrigation system. 


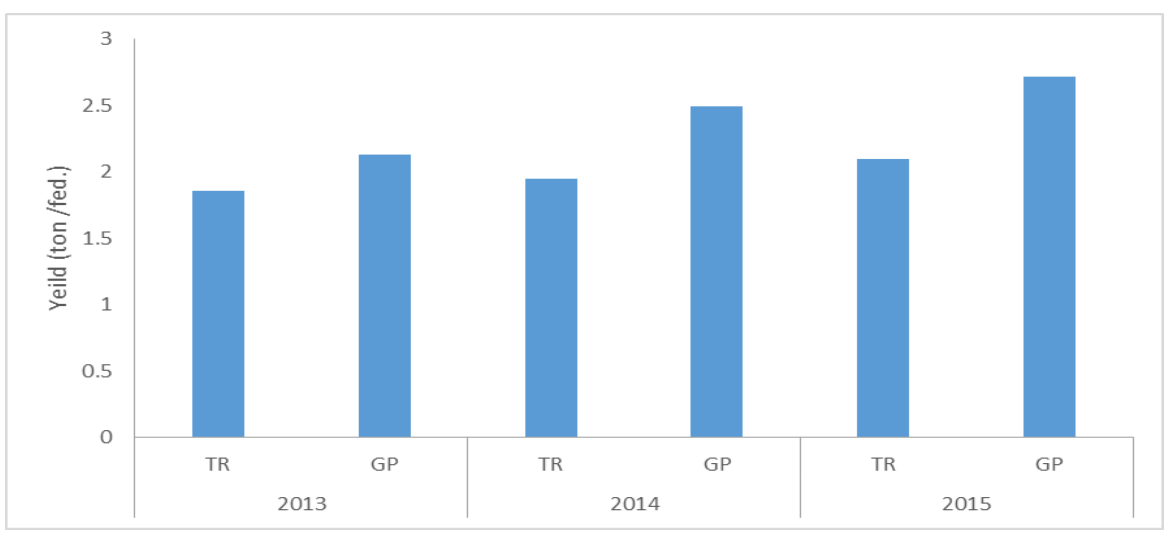

Figure (5). Yield of wheat crop under traditional surface irrigation (TR) and gated pipe systems (GP).

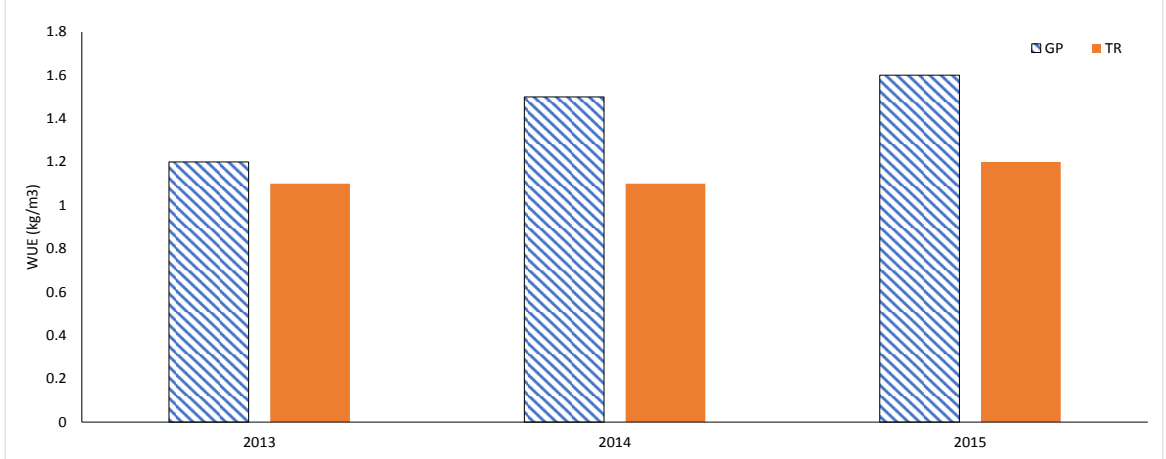

Figure (6).Water use efficiency (WUE) of wheat crop under traditional surface irrigation (TR) and gated pipe systems (GP).

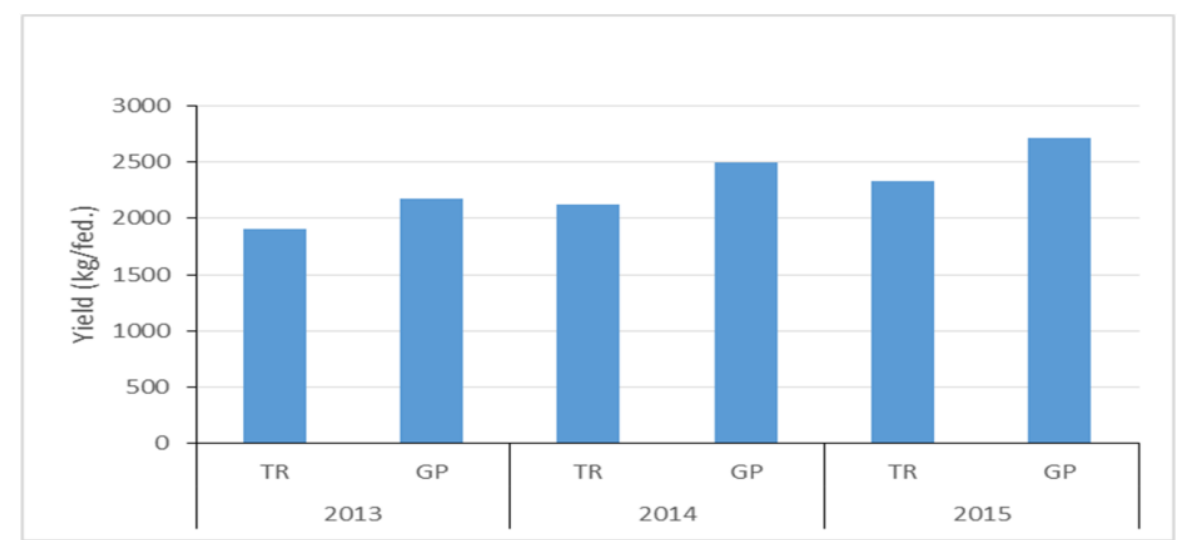

Figure (7). Yield of maize crop under traditional surface irrigation (TR) and gated pipe systems (GP). 


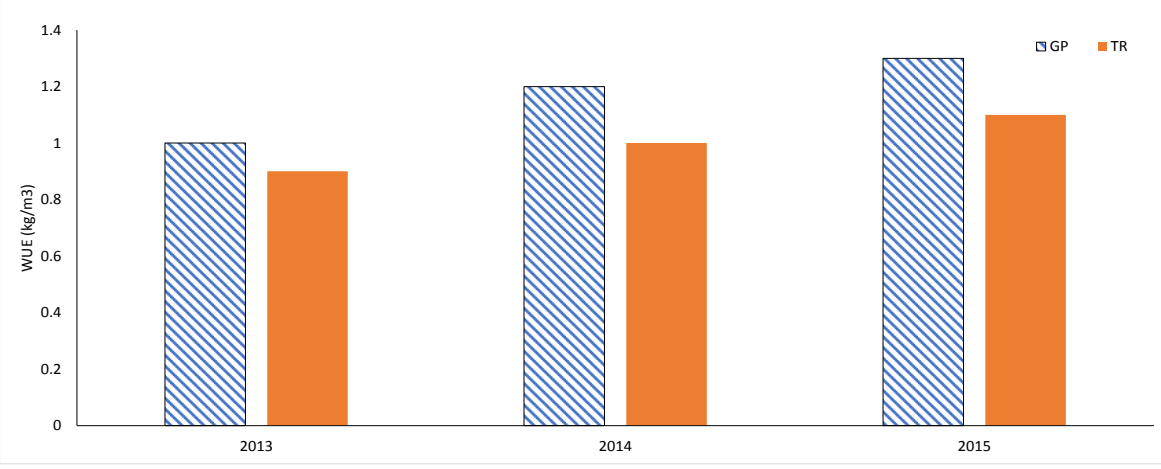

Figure (8). Water use efficiency (WUE) of maize crop under traditional surface irrigation (TR) and gated pipe systems (GP).

\subsection{Electrical conductivity of drainage water}

Drainage water properties and its quantity were measured during the seasons of 2013, 2014 and 2015; the results showed that, there are no different between the two irrigation systems. Electrical conductivity (EC) of drainage water for all of them decreased from about 2.9 at 2013 to 1.8 $\mathrm{ds}^{-1}$ at the end of 2015 season by the same percentage, but on 13 august 2013 and 6 April 2015, the values of (EC) were increased suddenly under gated pipes system duo to the increase of channel EC in this period, figure (9) explain the relation between the drainage rate with time under surface traditional and gated pipes irrigation systems since 2013, 2014 and 2015 in figure (10).

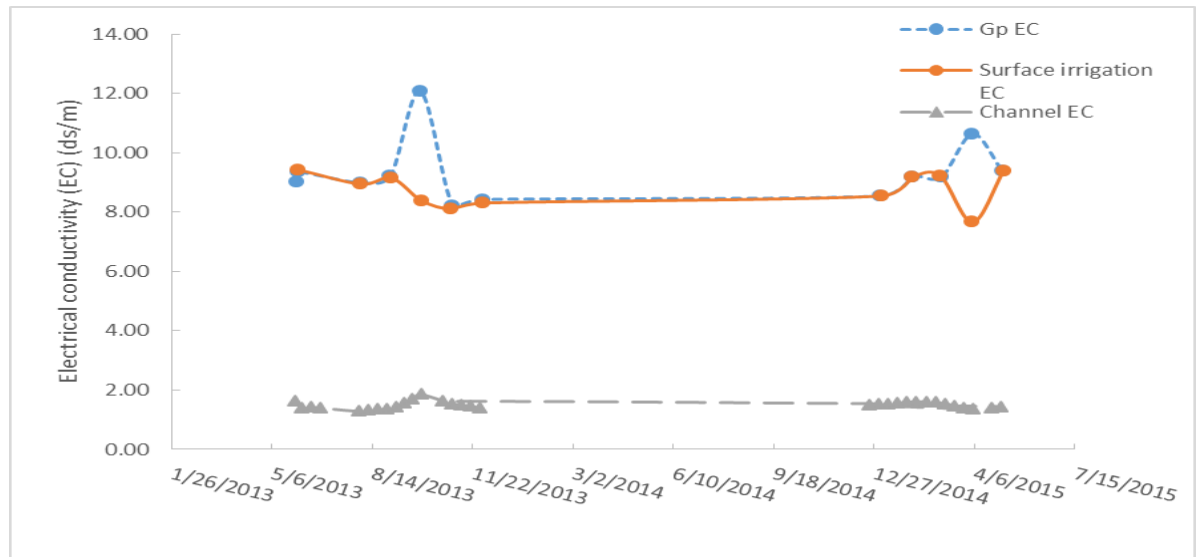

Figure (9). Electrical conductivity of drainage water during the growing seasons. Statistical analysis explains that, there isn't any significant difference between the two irrigation systems, but in August, 14, 2013 drainage rate 
and drain discharge were decreased with TR from May to April, also, with GP it suddenly decrease throw the distance from August, 14, 2013 to November, 22, 2013 for 8 and $250 \mathrm{~m}^{3}$ day $^{-1}$ to 1 and $45 \mathrm{~m}^{3}$ day $^{-1}$ for drainage rate and danger discharge respectively.

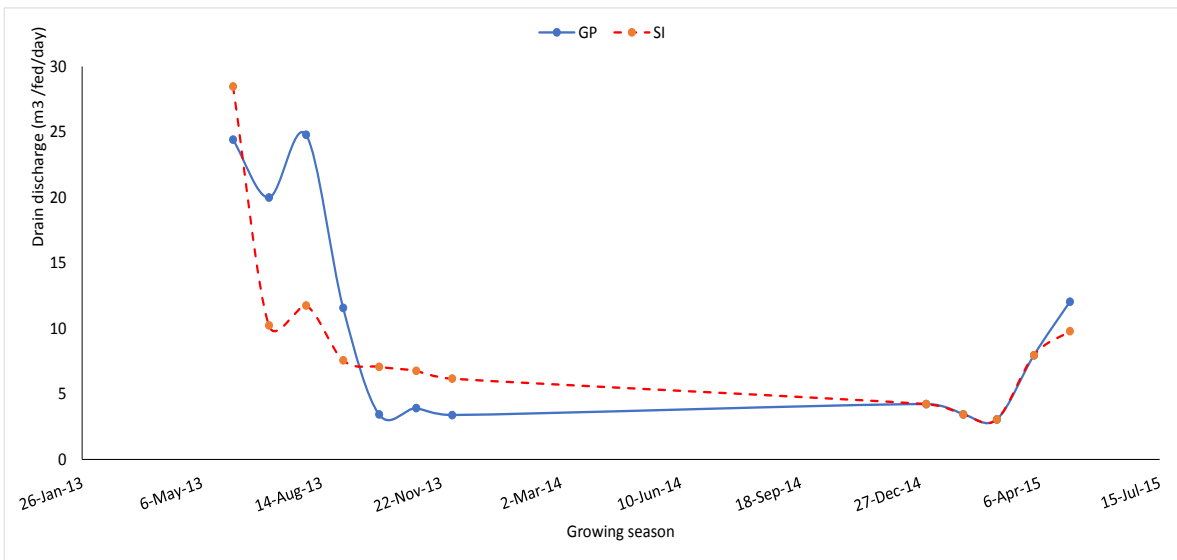

Figure (10). Rate of the drainage water during the growing seasons

\subsection{Electrical conductivity (EC) of Soil}

Figure (11) shows the seasonal course of soil (EC) in root zone during the period from 2013 until 2015, the result showed that, soil (EC) decreased from $12.9 \mathrm{ds} \mathrm{m}^{-1}$ at the first year of study to $1.64 \mathrm{ds} \mathrm{m}^{-1}$ at the third year of study. Soil permeability coefficient was significant by 0.013 and its value under traditional surface irrigation system was higher than under a gated pipe, but soil infiltration rate, water table discharge and drainage rate and (EC) of drainage were not significant as presented in Fig.(11).

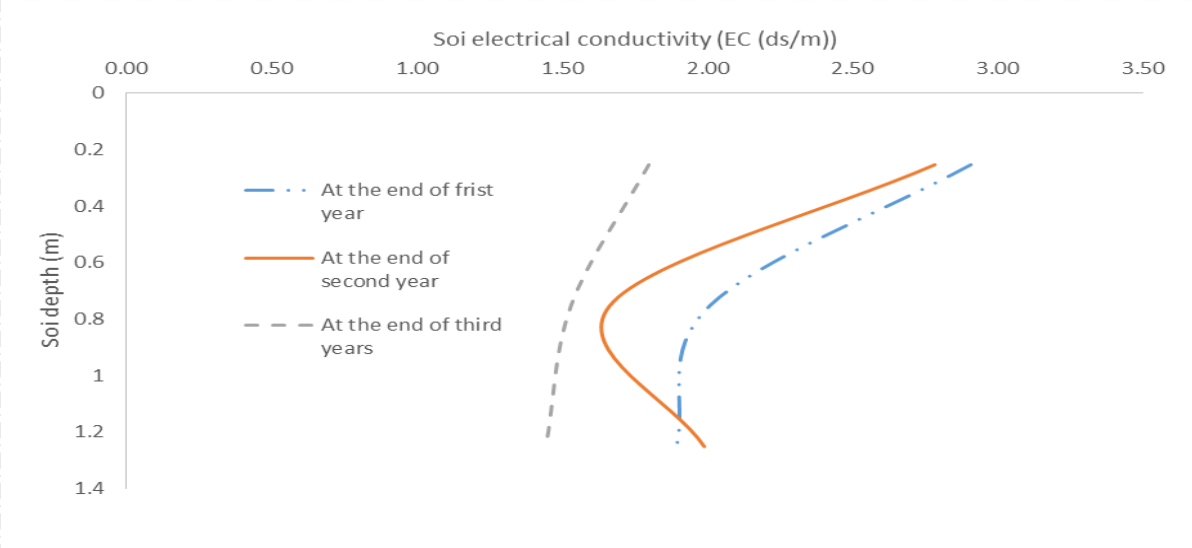

Figure (11). Changing of Electrical conductivity with soil depth of soil (EC) during the growing seasons. 
The statistical analysis showed that, the effects of irrigation system on the residual soil content of elements were significant only for residual potash (0.002), $\mathrm{HCO}_{3}(0.000)$ and $\mathrm{SO}_{4}$ of soil contents. Potash content under surface irrigation was higher than with gated pipes irrigation system.

\section{CONCLUSION}

The results obtained revealed that, values of yield under gated pipes were higher by $24.4 \%$ and $16.3 \%$ than the corresponding ones under the traditional surface irrigation system for wheat and maize, respectively. In addition to, the using of GP increased the WUE by $26.5 \%$ and $16.7 \%$ than the corresponding ones under traditional surface irrigation system for wheat and maize, respectively. Also, using gated pipes reduced both soil (EC) and (pH). Moreover, the quantity of drainage water under traditional system was higher than under the gated pipe system, therefore, the (EC) of drainage water under gated pipes system was higher than the corresponding one under the traditional method.

\section{REFERENCES}

Ali, O. A., and Mohammed, A. S. (2015). Performance Evaluation of Gated Pipes Technique for Improving Surface Irrigation Efficiency in Maize Hybrids. Retrieved 12 10, 2017, from http://file.scirp.org/html/10-3001106_56816.htm

Abou Kheira, A.A. (2009) Comparison among Different Irrigation Systems for Deficit-Irrigated Corn in the Nile Valley. Agricultural Engineering International: CIGR Journal, 14, 1-25.

El Sayed, G.H. 1998. Hydraulic studies for gated pipes distribution system. Egypt. J. agric. Res., 76(1). 387-403

El-Quosy, D. (2011) Water Resources in Egypt: Availability and Allocation. Proceedings of the Egypt-Australia-ICARDA Workshop on Farm Water Use Efficiency, Cairo, 26-29 July 2011, 9.

Groote, H. D., and Kimenju, S. C. (2012). Consumer Preferences for Maize Products in Urban Kenya. Food and Nutrition Bulletin, 33(2), 99-110. Retrieved 7 18, 2019, from https://ncbi.nlm.nih.gov/pubmed/22908691

ICARDA (2011). Water and Agriculture in Egypt: Types of agricultural land in Egypt. Proceeding of the Egypt-Australia-ICARDA workshop on On-Farm water use Efficiency, Cairo, 26-29 July 2011,9. 
Osman, H.E (2000). Gated pipes techniques for improved surface irrigation. Annals of Agricultural Science Cairo 1: 145-155.

Karrou, M and Oweis, Theib and Abou El Enein, R and Morgan, Sherif. (2012). Yield and water productivity of maize and wheat under deficit and raised bed irrigation practices in Egypt. African journal of agricultural research. 7. 1755-1760.

Yates, D. N., and Strzepek, K. M. J. C. C. (1998). An assessment of integrated climate change impacts on the agricultural economy of Egypt. 38(3), 261-287

الملخص العربى

تأثير نظام الري ذو الأنابيب المبوبة ونظام الري السطحي التقليدي مع المياه

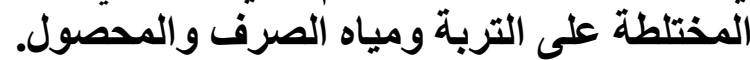

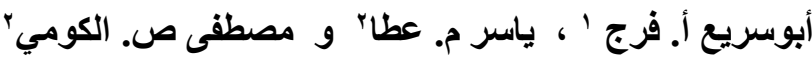

أجريت هذه الدر اسة في سهل الطينة (شمال غرب شبه جزيرة سيناء ، مصر ) خلال مو اسم النمو

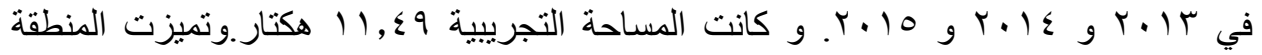

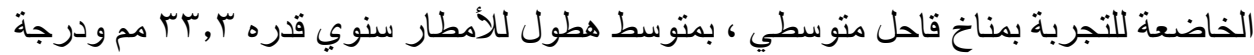

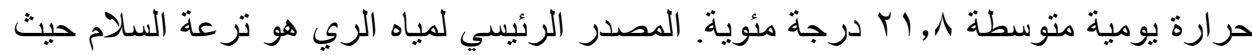

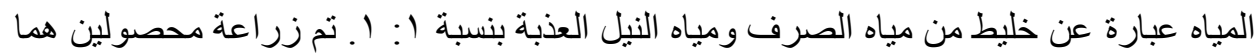

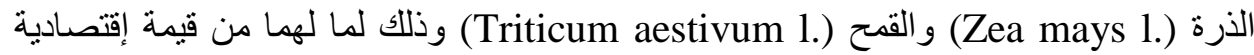

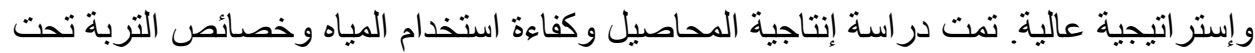

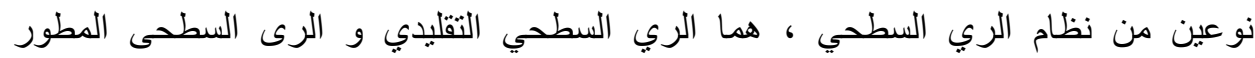

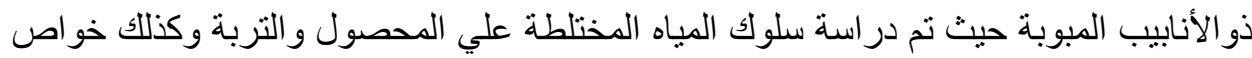

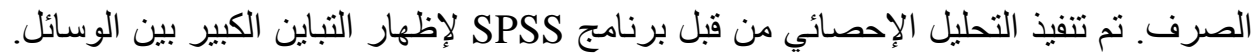

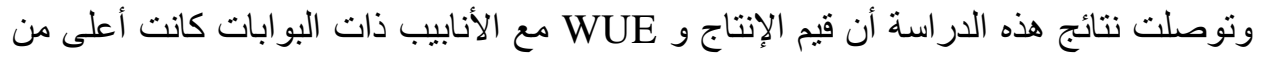

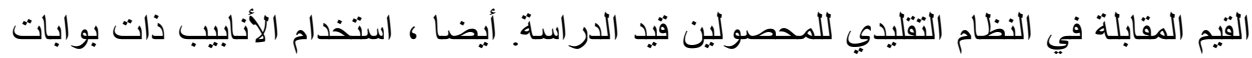

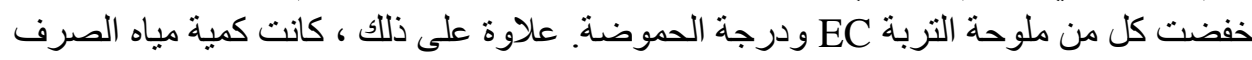

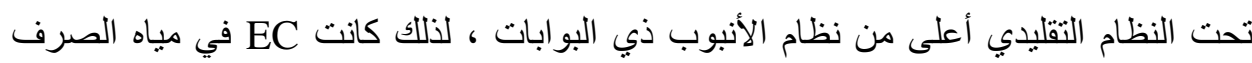

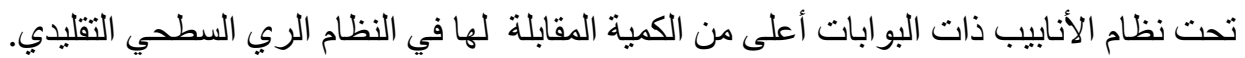

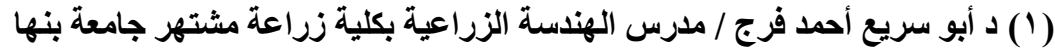

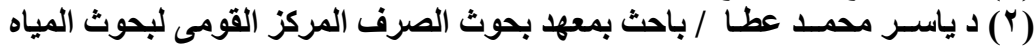

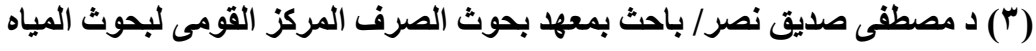

